\title{
Review of Seismic Velocity Model From Checkshot Survey Data for Parts of Onshore Niger Delta Sedimentary Basin, Nigeria
}

\author{
Emujakporue, Godwin Omokenu ${ }^{1}$ and Nwosu, Leonard I. \\ Department of Physics, University of Port Harcourt, Rivers State, Nigeria
}

\begin{abstract}
Subsurface layers'velocity is very important in determining the depth, dip, and horizontal location of reflectors and refractors, for predicting velocities at various depth, time-depth conversion and calculation of sediment thickness in the subsurface and identification of structural closures for hydrocarbon exploration. The estimation of the subsurface velocity is a major challenge in exploration seismology. Accurate measurement of subsurface velocity has continued to receive great attention in the oil and gas industry. The seismic velocitydepth model was computed from check shot data from four exploratory wells in an onshore field in Niger Delta sedimentary basin. The velocity-depth model was obtained from computed surface velocity $V_{o}$ and compaction factor $k$, for the medium. The computed $V_{o}$ value ranges from 1824.55 to $1995.93 \mathrm{~m} / \mathrm{s}$. Similarly, the computed $K$ value ranges from 0.5 to $0.6165 \mathrm{~s}^{-1}$. The average regional surface velocity and compaction factor are $1915.92 \mathrm{~ms}^{-1}$ and $0.554 \mathrm{~s}^{-1}$ respectively. A linear velocity-depth model was obtained for the four wells within the depth investigated. The derived average velocity-depth model is: $v_{z}=1915.92+0.554 z$. The increase in velocity with depth may be due to the effect of sediment compaction resulting in decrease in porosity. The velocity model can be applied to seismic reflection data in order to determine the thickness and depth of subsurface layers, seismic depth imaging, and layer thickness estimation in the Niger Delta. This method provides a basis for better approximation of the depth structure of subsurface sediments and it can also be used to accurately estimate geologically important seismic events such as changes in facies, fractures, faults, and unconformities.
\end{abstract}

Keywords: :Niger Delta,Checkshot data, Surface Velocity, Compaction factor, depth- conversion.

\section{Introduction}

Knowledge of subsurface velocity values is essential in determining the depth, dip, and horizontal location of reflectors and refractors, in determining whether head waves and velocity distortions occur and in ascertaining the nature of rocks and their interstitial fluids from velocity measurements [1]. Seismic velocity estimation is the most important problem in exploration seismology because of it impacts on both processing and interpretation of seismic data. Velocities are measured directly in wells (sonic logs, well velocity surveys) and derived indirectly from normal moveout (NMO) relationships of the seismic reflections[2].

Seismic velocities are subject to variation both vertically and laterally. The velocity of sound in rock varies vertically with compaction of the rock, and with the type of rock in the layers. The compaction of the rock is caused by the weight of the rock on top of it, so that the deeper the rock, the more it is likely to be compacted and the higher the velocity tends to be.Velocity also varies horizontally with the lateral variations in the make-up of the layers. Lateral velocity variation can also be attributed to lithologic change, dip and faulting $[3,4]$.

Researchers have shown that velocity of most sedimentary basin increases with depth. Lithology, like velocity in these areas actually changes with burial depth rather than in discrete steps at boundaries. The rate of change is erratic and faster in near surface and decreases with a regular trend in deeper subsurface due to the effect of compaction. This is the basis of the instantaneous velocity-depth model which is been used by the oil and gas industries[5,6].

In hydrocarbon exploration,velocity models are used for stacking, migration and depth conversion. Velocity modeling in hydrocarbon exploration is also very important because the computed layer velocities are combined with seismic two-way travel times for depth conversion. The velocity of seismic wave propagation in Tertiary basin can be closely approximated by expressing it as a linear function of depth $[7,8,9]$. In an area that has been continually subsiding without any significant uplift, rocks should be at their maximum depth of burial and the velocity should depend mainly on depth, with relatively little regard for age, assuming no major lithologic changes. This situation is approximated in many areas where the velocity function is nearly the same over a large region. Conversely, in areas that were formerly much deeper and where rocks have been uplifted by different amounts, complex velocity is expected. The objectives of this study are to determine the surface velocity $\left(\mathrm{V}_{\mathrm{o}}\right)$, compaction factor $(\mathrm{k})$ and velocity function from Check shot data. The velocity function will be used for predicting vertical and lateral velocity and for converting seismic times to depths within the onshore Niger Delta. 


\section{Sumary of the Geology of the study Area}

The study area is located in the Niger Delta, Nigeria (Fig. 1). Niger Delta is situated within the Benue Trough system and it is a young sedimentary basin. Its development began after the Eocene tectonic phase. The thickness of the basin ranges between $10-12 \mathrm{~km}$ and it is made up of deltaic and shallow marine sediments mainly supply by rivers Niger and Benue[10].

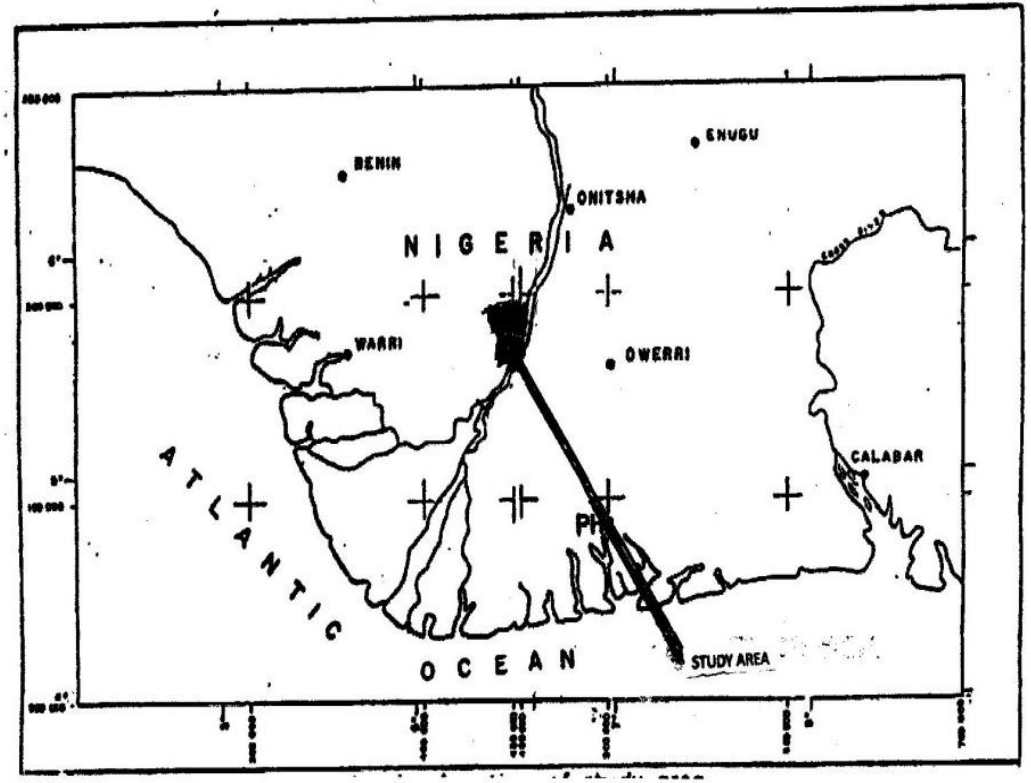

Fig. 1: Map of Niger Delta showing the location of the study area.

The geology of the Niger Delta is divided into three lithostratigraphies based on the sand-shale ratio [11]. These stratigraphic units are Akata, Agbada, and Benin Formations. The Akata Formation is the basal unit of the Niger Delta complex. It is of marine origin and composed of thick shale sequences that form potential source rock [11, 12, 13]. The Akata Formation is overlain by the Agbada Formation and it consists of fluviomarine sands, siltstones, and shales. The sandy parts constitute the main hydrocarbon reservoirs. The topmost lithostratigraphy is the Benin Formation and it is a continental deltaic sand. Shale diapirs, growth faults, and associated rollover anticlines are very common in the Niger Delta. Both structural and stratigraphy traps abound in the basin $[10,14,15]$.

\section{Materials and Methodology}

In most clastic environment, researchers have shown that the velocity of seismic wave propagation in Tertiary basins can be approximated by expressing it as a linear function of depth $[3,5]$ as:

$v_{z}=v_{0}+k z$

where,

$v_{z}=$ Velocity at depth $\left(\mathrm{ms}^{-1}\right)$

$v_{0}=$ surface velocity in $\mathrm{ms}^{-1}$

$\mathrm{K}=$ the rate of velocity increase with depth or the compaction factor in $\mathrm{s}^{-1}$ for the medium

$\mathrm{Z}=\operatorname{Depth}(\mathrm{m})$

The above equation assumed that instantaneous velocity, $v_{z}$ changes linearly with lithology and depth (Z). The surface velocity, $v_{0}$ and the compaction factor, $\mathrm{K}$, have been described as parameters of convenience to provide a simple description of how the instantaneous velocity varies with depth [16]. Different velocity models such as linear and curvilinear have been proposed by some researchers [7]. In this work, effort has been made to obtain the value of $v_{0}$ and $\mathrm{K}$ from available check shot (well survey) data. The data used for this work are check shot data obtained from four exploratory oil wells and the base map of the study area. The check shot surveyed was made by firing a seismic source near the surface, and detecting the seismic waves with a geophone suspended at series of depth in the well (Fig. 2). The shots are not located directly at top of the well so the sound travels a slanting path, and the times are corrected to vertical paths by trigonometry. At each recording 
position in the well, the seismic time to the depth is measured and the velocity is calculated. This was done by reading the first breaks at the different positions of the geophone in the well.

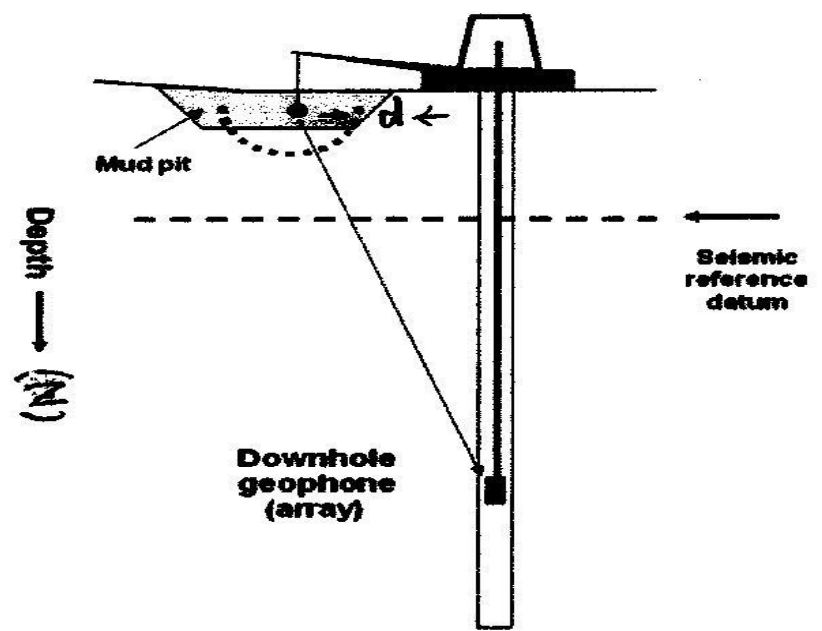

Fig. 2: Schematic Representation of a Typical Checkshot Velocity Survey on Land （modified from [5])

These one-way times were doubled to be compared with seismic sections. The time-depth (T-Z) data from Checkshots, when plotted, are usually fitted with a smooth curve of the anti-hyperbolic cosine type according to the equation:

$t=\frac{1}{k} \cosh ^{-1}\left\{1+k^{2}\left(d+z^{2}\right) / 2 v_{0}\left(v_{0}+k z\right)\right\}$

Where,

$v_{0}=$ surface velocity $(\mathrm{m} / \mathrm{s})$

$\mathrm{t}=$ one-way time $(\mathrm{s})$

$\mathrm{k}=$ compaction factor $\left(\mathrm{s}^{-1}\right)$

$\mathrm{d}=$ distance from shot point to the centre of the borehole

$\mathrm{z}=$ depth of geophone in the well.

When the shot point is located at the well-head $(\mathrm{d}=0)$, then equation 1 above becomes:

$t=\frac{1}{k} \cosh ^{-1}\left\{1+k^{2} z^{2} / 2 v_{0}\left(v_{0}+k z\right)\right\}$

Solving equation 2 for $v_{0}$, we obtained;

$v_{0}=\left(\frac{\mathrm{kz}}{2}\right)\left[\left\{1+2\left[\left(\frac{d}{2}\right)+1\right] /(\cosh k t-1)\right\}^{\frac{1}{2}}-1\right]$

Similarly, when $\mathrm{d}=0$, then;

$v_{0}=\left(\frac{\mathrm{kz}}{2}\right)\left[\{1+[2] /(\cosh k t-1)\}^{\frac{1}{2}}-\right]$

To obtain suitable values for $v_{0}$ and $\mathrm{k}$, if they exist, to fit the above equations and the check shot data, it is necessary to have two equations, since there are two unknown $\left(v_{0}\right.$ and $\left.\mathrm{k}\right)$. In order to obtained the values of $v_{0}$ and $\mathrm{k}$, equation 5 was solved systematically using the following steps.

(i). After examining the points of the time-depth curves from the point of view of smoothness, then three to four (3-4) sets of depth and their corresponding time were chosen.

(ii). Arbitrary values of $\mathrm{k}$ were choosing covering the range in which its final compaction value will probably lie.

(iii). The value of $v_{0}$ was then computed for each arbitrary value of $\mathrm{k}$.

(iv). The next step is to find how $v_{0}$ varies with the corresponding value of $\mathrm{k}$ for each set of data. This was done by plotting the computed values of $v_{0}$ against the corresponding value of $\mathrm{k}$ for the three to four sets of depth values obtained from the same well on one linear graph. The point of intersections for the curves is an indication of the local value of $v_{0}$ and $\mathrm{k}$ within the borehole.

(v). The various local values of $v_{0}$ and $\mathrm{k}$ obtained from the various wells were then average to obtain the regional value of $v_{0}$ and $\mathrm{k}$ for the surveyed area.

\section{Results and Discussion}

The computed values of $v_{0}$ from the arbitrary values of $\mathrm{k}$, for the four wells are shown in Table 1 . The arbitrary values of $\mathrm{k}$ ranges from 0.1 to $0.9 \mathrm{~s}^{-1}$. The values of depths and their corresponding one way-time used for the work are shown in column 1 of the Table. The plot of the computed values of $v_{0}$ versus the corresponding arbitrary values of $\mathrm{k}$ are shown in Figures 3-6. It can be observed that the three to four curves for 
each well passed through a common point.These points of intersections are the local values of $v_{0}$ and $\mathrm{k}$ for each well location. The local values of $v_{0}$ obtained for well 1 , well 2 , well 3 and well 4 are 1990.87, 1853.75, 1824.55 , and $1995.93 \mathrm{~m} / \mathrm{s}$ respectively. Furthermore, the local value of $\mathrm{k}$ obtained from the point of intersection for well 1 , well 2 , well 3 and well 4 are $0.5,0.616,0.6$ and $0.5 \mathrm{~s}^{-1}$ respectively.

Table 1: Computed values of $V_{0}$ from arbitrary values of $K$ for well 1,2,3 and 4 .

\begin{tabular}{|c|c|c|}
\hline Well 1 & $K\left(s^{-1}\right)$ & $v_{0}\left(m^{-1}\right)$ \\
\hline $\begin{array}{l}H=834 m \\
T=0.764 \mathrm{~s}\end{array}$ & $\begin{array}{l}0.1 \\
0.5 \\
0.6 \\
0.7 \\
0.8 \\
0.9\end{array}$ & $\begin{array}{l}2141.8 \\
1981.38 \\
1942.59 \\
1904.34 \\
1866.61 \\
1829.41\end{array}$ \\
\hline $\begin{array}{l}H=1730 \mathrm{~m} \\
T=1.459 \mathrm{~s}\end{array}$ & $\begin{array}{l}0.1 \\
0.5 \\
0.6 \\
0.7 \\
0.8 \\
0.9\end{array}$ & $\begin{array}{l}2286.04 \\
1965.22 \\
1890.23 \\
1817.3 \\
1746.4 \\
1677.6\end{array}$ \\
\hline $\begin{array}{l}H=3061 \mathrm{~m} \\
T=2.279 \mathrm{~s}\end{array}$ & $\begin{array}{l}0.1 \\
0.5 \\
0.6 \\
0.7 \\
0.8 \\
0.9\end{array}$ & $\begin{array}{l}1540.23 \\
1993.13 \\
1871.8 \\
1755.86 \\
1645.366 \\
1540.23\end{array}$ \\
\hline $\begin{array}{l}H=3927 \mathrm{~m} \\
T=2.745\end{array}$ & $\begin{array}{l}0.1 \\
0.5 \\
0.6 \\
0.7 \\
0.8 \\
0.9\end{array}$ & $\begin{array}{l}266.93 \\
1990.87 \\
1843 \\
1703 \\
1572.2 \\
1448.94\end{array}$ \\
\hline
\end{tabular}

\begin{tabular}{|c|c|c|}
\hline Well2 & $K\left(s^{-1}\right)$ & $V_{0}\left(m s^{-1}\right)$ \\
\hline $\begin{array}{l}H=500 \mathrm{~m} \\
T=500 \mathrm{~ms}\end{array}$ & $\begin{array}{l}0.1 \\
0.5 \\
0.62 \\
0.7 \\
0.8 \\
0.9\end{array}$ & $\begin{array}{l}1975.104 \\
1877.6 \\
1853.75 \\
1830.1 \\
1806.7 \\
1783.43\end{array}$ \\
\hline $\begin{array}{l}H=1750 \mathrm{~m} \\
T=1500 \mathrm{~ms}\end{array}$ & $\begin{array}{l}0.1 \\
0.5 \\
0.62 \\
0.7 \\
0.8 \\
0.9\end{array}$ & $\begin{array}{l}2246.93 \\
1923.11 \\
1847.58 \\
1774.2 \\
1702 \\
1633.76\end{array}$ \\
\hline $\begin{array}{l}\mathrm{H}=3500 \mathrm{~m} \\
\mathrm{~T}=2550 \mathrm{~ms}\end{array}$ & $\begin{array}{l}0.1 \\
0.5 \\
0.62 \\
0.7 \\
0.8 \\
0.9\end{array}$ & \begin{tabular}{|l|}
2573.8 \\
1962.44 \\
1827.69 \\
1699.94 \\
1579.07 \\
1464.91 \\
\end{tabular} \\
\hline
\end{tabular}

\begin{tabular}{|c|c|c|}
\hline Well3 & $K\left(s^{-1}\right)$ & $V_{0}\left(m^{-1}\right)$ \\
\hline $\begin{array}{l}\mathrm{H}=500 \mathrm{~m} \\
\mathrm{~T}=500 \mathrm{~ms}\end{array}$ & $\begin{array}{l}0.1 \\
0.5 \\
0.6 \\
0.7 \\
0.8 \\
0.9\end{array}$ & $\begin{array}{l}1975.1 \\
1877.6 \\
1853.75 \\
1830.1 \\
1806.66 \\
1783.4\end{array}$ \\
\hline $\begin{array}{l}H=1500 \mathrm{~m} \\
T=1350 \mathrm{~ms}\end{array}$ & $\begin{array}{l}0.1 \\
0.5 \\
0.6 \\
0.7 \\
0.8 \\
0.9\end{array}$ & $\begin{array}{l}2148.06 \\
1868.3 \\
1802.52 \\
1738.4 \\
1675.96 \\
1615.15\end{array}$ \\
\hline $\begin{array}{l}H=2500 \mathrm{~m} \\
T=2000 \mathrm{~ms}\end{array}$ & $\begin{array}{l}0.1 \\
0.5 \\
0.6 \\
0.7 \\
0.8 \\
0.9\end{array}$ & $\begin{array}{l}2377.1 \\
1926.87 \\
1824.55 \\
1726.3 \\
1631.93 \\
1541.52\end{array}$ \\
\hline $\begin{array}{l}H=3500 \mathrm{~m} \\
T=2550 \mathrm{~ms}\end{array}$ & $\begin{array}{l}0.1 \\
0.5 \\
0.6 \\
0.7 \\
0.8 \\
0.9\end{array}$ & $\begin{array}{l}2573.8 \\
1962.44 \\
1827.69 \\
1699.94 \\
1579 \\
1464.9\end{array}$ \\
\hline
\end{tabular}

\begin{tabular}{|c|c|c|}
\hline Well 4 & $K\left(s^{-1}\right)$ & $V_{0}\left(m s^{-2}\right)$ \\
\hline $\begin{array}{l}H=915 \mathrm{~m} \\
T=0.968 \mathrm{~s}\end{array}$ & $\begin{array}{l}0.1 \\
0.5 \\
0.6 \\
0.7 \\
0.8 \\
0.9\end{array}$ & $\begin{array}{l}2141.8 \\
1670.96 \\
1629.3 \\
1588.3 \\
1548.1 \\
1508.6\end{array}$ \\
\hline $\begin{array}{l}H=1982.5 \mathrm{~m} \\
T=1.806 \mathrm{~s}\end{array}$ & $\begin{array}{l}0.1 \\
0.5 \\
0.6 \\
0.7 \\
0.8 \\
0.9\end{array}$ & $\begin{array}{l}2286.04 \\
1737 \\
1654.3 \\
1574.2 \\
1497.12 \\
1422.86\end{array}$ \\
\hline $\begin{array}{l}H=3050 \mathrm{~m} \\
T 2.5 \mathrm{~s}\end{array}$ & $\begin{array}{l}0.1 \\
0.5 \\
0.6 \\
0.7 \\
0.8 \\
0.9\end{array}$ & $\begin{array}{l}2536.1 \\
1736.4 \\
1618.5 \\
1506.75 \\
1400.9 \\
1300.8\end{array}$ \\
\hline $\begin{array}{l}H=3812 \mathrm{~m} \\
T=2.96 \mathrm{~s}\end{array}$ & \begin{tabular}{l|}
0.1 \\
0.5 \\
0.6 \\
0.7 \\
0.8
\end{tabular} & $\begin{array}{l}2669.3 \\
1742.7 \\
1602.6 \\
1471.2 \\
1348.4\end{array}$ \\
\hline
\end{tabular}



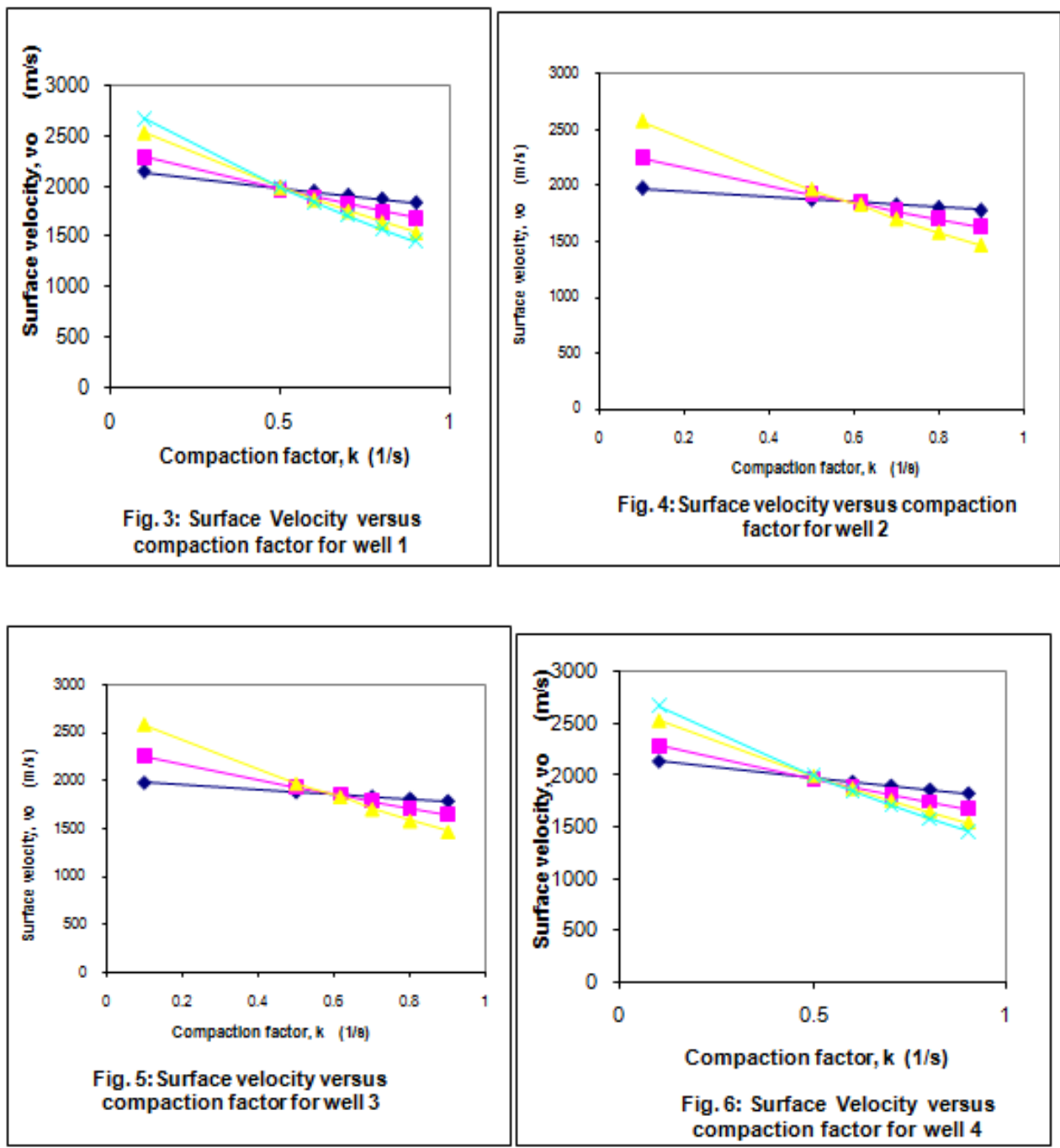

The velocity-depth functions for the four wells were obtained by substituting the computed values of $v_{0}$ and $\mathrm{k}$ into the model equation 1 . The velocity-depth functions are given as:

$$
\begin{aligned}
& V_{1 z}=1990.87+0.5 z \\
& V_{2 z}=1853.75+0.616 z \\
& V_{3 z}=1824.55+0.6 z \\
& V_{4 z}=1995.93+0.5 z
\end{aligned}
$$

Where $v_{1 z}$ to $v_{4 z}$ are the velocity depth functions for well 1,2,3 and 4 respectively.

The average regional surface velocity and compaction factor for the study area are $1915.92 \mathrm{~ms}^{-1}$ and $0.554 \mathrm{~s}^{-}$ ${ }^{1}$ respectively. The regional velocity-depth function for the study area is given as:

$$
V_{z}=1915.92+0.554 z
$$

This empirical model satisfies the condition that the velocity increases linearly with depth due to compaction.The lateral variation in $v_{0}$ and $\mathrm{k}$ within the study area might be as a result of lithology change and faulting (growth faults) in the subsurface. The map of the surface velocity, $v_{0}$ distribution within the region is shown in Fig. 7. The values increase toward the central portion. The linear vertical velocity trend is also an indication that the area has been subsiding gradually without any significant uplift. In fact, $\mathrm{V}_{0}$ and $\mathrm{K}$ are convenient ad-hoc parameters, in which are lumpedtogether the effects of several factors that determine the compressionalwave velocity of rock material of a lithostratigraphiclayer. Among these factors are type and stratification of sediments, pore fluid regime, maximum burial depth, uplift and exhumation [17]. The above velocity trend shows that the Tertiary Niger Delta has been undergoing subsidence without any significant uplift. 


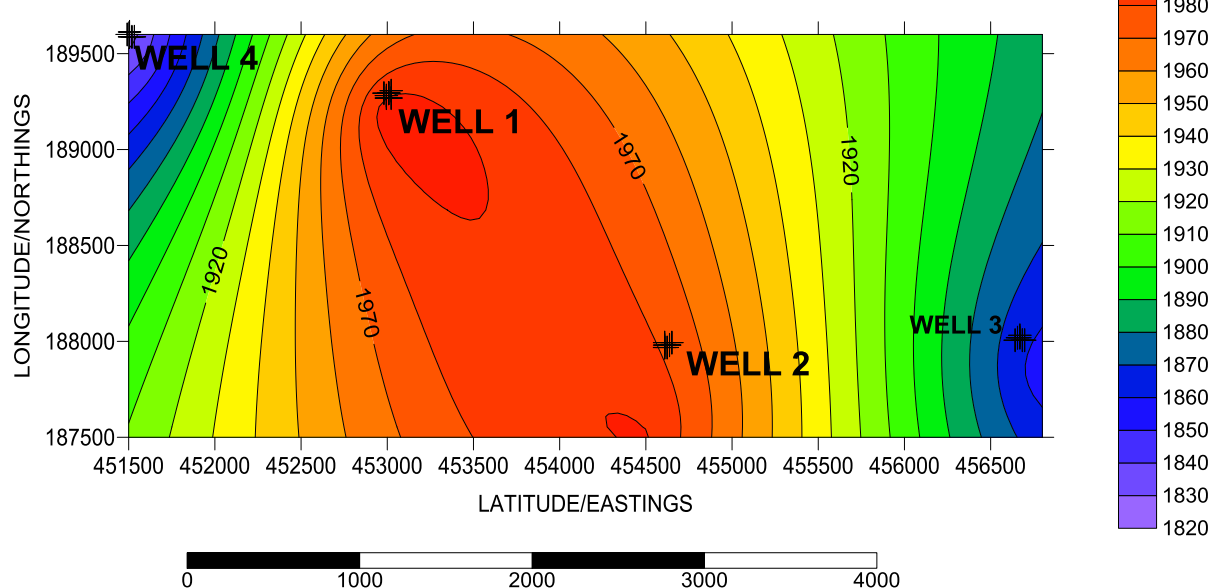

Fig. 7: Map of Surface Velocity, $v_{0}$ Distribution in the Study Area.

The map of the lateral variation of the values of $k$ in the studied area is shown in Fig.8. The computed value of $\mathrm{k}$ is not constant but varies slightly from well to well. The values of $\mathrm{k}$ decrease toward the central portion. This slight lateral variation gives an indication of the sediments transport and deposition sequence within this field. Vertical velocity changes within this field depend on $k$, compaction factor of these clastic sediments.The average value of $0.554 \mathrm{~s}^{-1}$ obtained for $k$ defines the rate at which velocity increases with depth in the study area.
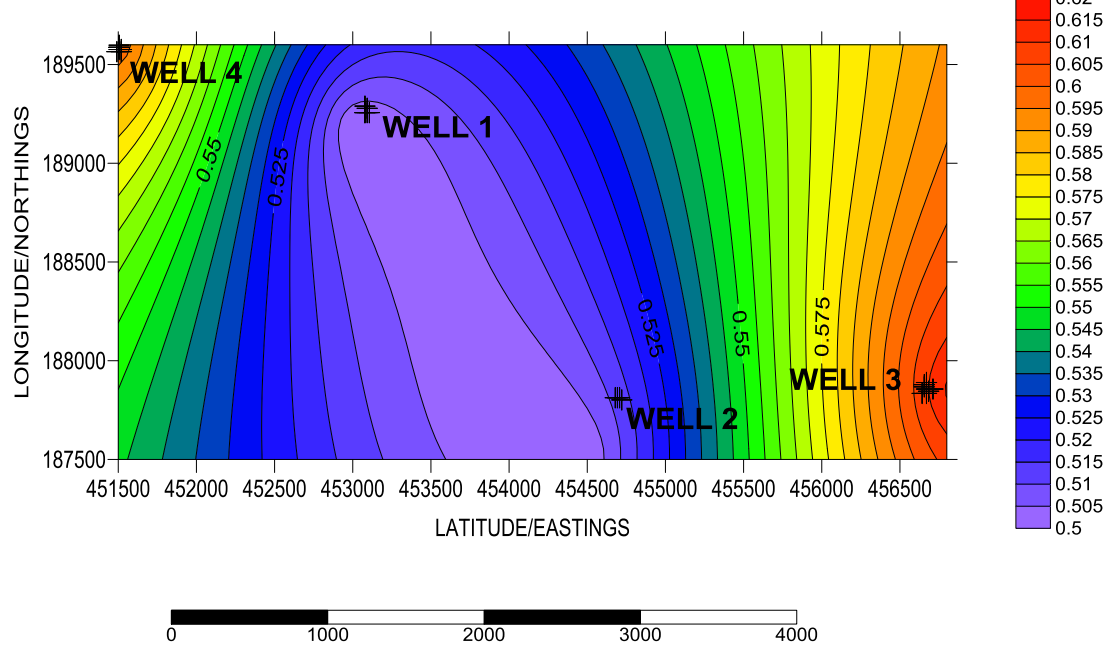

Fig.8: K-Gradient Contour Map of the Study Area.

The regional velocity-depth function (equation 10) was used to generate the graph shown in Fig. 9. The curve shows that velocity increases linearly with depth in the subsurface within the survey depth in the basin. This increase in velocity with depth may be attributed to sediment compaction due to overburden weight of deposited sediment. Sediment compaction causes a decrease in porosity with depth and dewatering of sediments. 


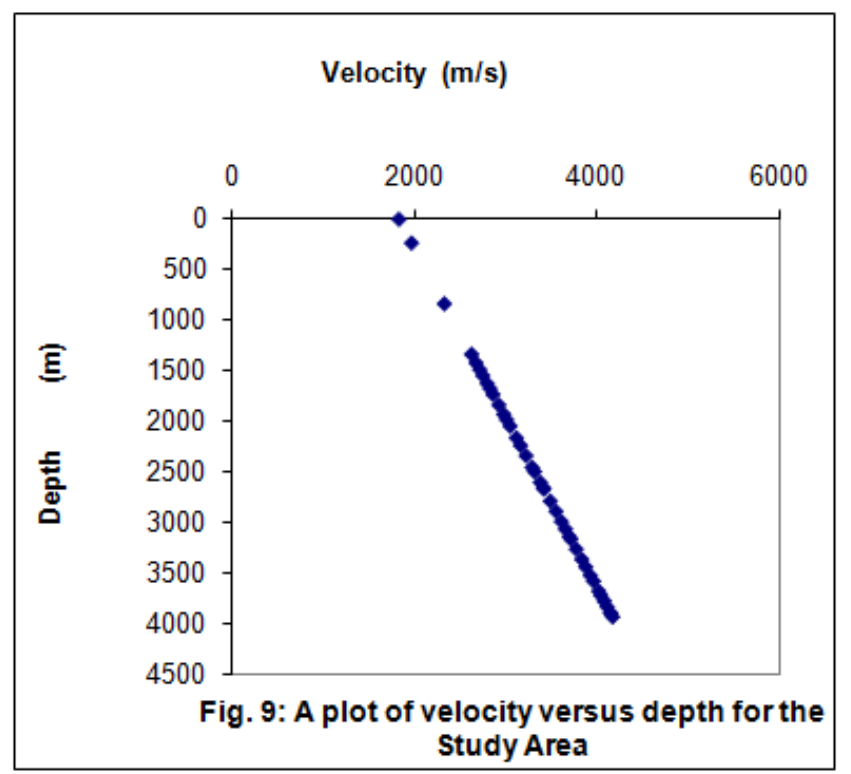

\section{Conclusion}

A linear velocity model has been determined from checkshot data for parts of the Niger Delta sedimentary basin for depth conversion. The computed average regional surface velocity and compaction factor are $1915.92 \mathrm{~ms}^{-1}$ and $0.554 \mathrm{~s}^{-1}$ respectively. The derived velocity function provides a basis for conveniently predicting velocities at various depth intervals useful in time-depth conversion of the subsurface sediments of the Niger Delta. In this region, with it's relatively homogeneous, normally pressured siliciclastic fill, asimple $\mathrm{V}_{0^{-}}$ $k$ model for depth conversion as shown in this work gives good results, but care should be taken when applying such a model to other areas having complex geology and abnormal pressure.

\section{References}

[1]. Sheriff, R. and Geldart, L., 1995. Exploration Seismology, $2^{\text {nd }}$ ed: Cambridge University Press.

[2]. Lines, L. R. and Newrick, R. T., 2005. Fundamentals of Geophysical Interpretation. Society of Exploration Geophysics. Geophysical monograph series; no. 13, 274p

[3]. Telford, W.M., L.P. Geldart, P.E. Sheriff, and D.A. Keys. 1976. Applied Geophysics. Cambridge University Press: London, UK. 860.

[4]. Coffen, J. A., 1984. Interpreting Seismic Data. Penwell Publishing Company,Tusla, Oklahoma. pp. 39-118.

[5]. Alaminiokuma, G. I.,and C.C. Ugbor 2010. Analytical Velocity Model for Depth Conversion in the Subsurface Facies of Agbada Formation in the Niger Delta, Nigeria. The Pacific Journal of Science and Technology, Vol 11. (1), 563-575

[6]. Smallwood, J. R. 2002. "Use of V0 - K Depth Conversion from Shelf to Deep-water: How Deep is that Bright spot?". Firstbreak, EAGE. 20(2):99 - 107.

[7]. Al-Chalabi, M. 1997b. "Time-Depth Relationships for Multilayer Depth Conversion”. Geophysical Prospecting. 45:715-720.

[8]. Al-Chalabi, M. 2001. "The Use of Instantaneous Velocity in Uplift Investigations". Geophysical Prospecting. 49(6):645 - 655.

[9]. Ravve, I.,and Z. Koren. 2006. "Exponential Asymptotically Bounded Velocity Model; Part 1 - Effective Models and Velocity Transformations". Geophysics. 71(3): T53 - T65.

[10]. Doust, H., and Omatsola, E., 1990. Niger Delta, in, Edwards, J. D., and Santogrossi, P.A., eds., Divergent/passive Margin Basins, AAPG Memoir 48: Tulsa, American Association of Petroleum Geologists, 239-248.

[11]. Kulke, H., 1995. Nigeria, in, Kulke, H., ed., Regional Petroleum Geology of the World. Part II: Africa, America, Australia and Antarctica: Berlin, GebrüderBorntraeger, 143-172.

[12]. Stacher, P., 1995. Present understanding of the Niger Delta hydrocarbon habitat, in, Oti, M.N., and Postma, G., eds., Geology of Deltas: Rotterdam, A.A. Balkema, 257-267.

[13]. Klett, T. R., Ahlbrandt, T. S., Schmoker, J. W. and Dolton, J. L., 1997. Ranking of the world's oil and gas provinces by known petroleum volumes: U.S. Geological Survey Open-file Report-97-463, CD-ROM.

[14]. Evamy, B. D., Haremboure, J., Kamerling, P., Knaap, W. A., Molloy, F. A. and Rowlands, P. H. 1978. Hydrocarbon habitat of Tertiary Niger Delta. American Association of Petroleum Geologists Bulletin, 62, 1-39

[15]. Whiteman, A. 1982. Nigeria - It's Petroleum Geology Resources and Potential. Graham and Trotman: London, UK. 394.

[16]. Al-Chalabi, M. 1997a. "Parameters Non-Uniqueness in Velocity Versus Depth Functions". Geophysics. 62(3):970 - 979.

[17]. Japsen, $\boldsymbol{P}$., 2000. Investigation of multi-phase erosion using reconstructed shale trends based on sonic data. Sole Pit axis, North Sea. Global and Planetary Change 24: 189-210. 